NOTA NECROLÓGICA 


\section{EN RECUERDO DE ORLANDO TOVAR}

Cuando este número de la Revista de Derecho Político se encontraba ya en imprenta, nos llega de Venezuela la triste noticia de que nuestro compañero del Consejo de Redacción de la Sección Iberoamericana, doctor Orlando Tovar Tamayo, habia fallecido después de una larga y penosa enfermedad, lo que no le impidió recientemente publicar en su número 32 , el primero que incluia la Sección Iberoamericana, un excelente trabajo sobre el Régimen Político Venezolano.

Difícil será la sustitución del eminente jurista como miembro del Consejo de Redacción de nuestra Revista, de la que fue decidido impulsor y entusiasta sin límite en la idea de que existiera un medio de difusión que agrupase a constitucionalistas españoles e iberoamericanos con el fin de contribuir a consolidar el Estado Social de Derecho en nuestros paises.

A la digna empresa de que Democracia y Justicia fueran algo habitual y no excepcional en América, dedicó su vida el maestro venezolano; dicho afán quedó demostrado a lo largo de su trayectoria, no sólo por su obra jurídica y docente, sino en cuantos puestos de representatividad pública le llevó el sentido de la responsabilidad para con su Venezuela natal y el mundo iberoamericano; su paso al frente del Ministerio de Justicia estuvo marcado por una lucha tenaz para que la integración de todos los venezolanos en el sistema democrático fuese una realidad que imposibilitase una vuelta a los períodos de violencia y desvertebración del país. De su época de Embajador de la República de Venezuela en Chile, en los primeros tiempos de la Dictadura, nos queda el recuerdo de una Sede Diplomática que, como pocas, fue lugar de asilo y vía de salida para aquellos que, en difíciles momentos, debian huir de la barbarie desencadenada en el pais del sur.

Me contaba muchos años después, contemplando una puesta de sol, como sólo es posible hacerlo en Juan Griego en Isla Margarita, que en Chile pasó la peor noche de su vida, y lamentó por una sola vez que sus conocimientos académicos fueran sólo de Derecho, pues tuvo que atender él solo, el parto de una asilada en la Embajada, cuando el toque de queda silenciaba las calles de Santiago. 
Su anhelo de justicia le llevaría posteriormente a la Corte Interamericana de Justicia y al Senado de Venezuela, donde podemos seguir su obra en defensa de los derechos y libertades, de lo que valga como ejemplo, su definitiva intervención en favor del Recurso de Amparo, o su encendida defensa del régimen Parlamentario que él identificaba con el sistema democrático, ante la amenaza siempre constante del todopoderoso poder ejecutivo.

Recientemente, cuando ya su proceso de enfermedad era irreversible, tuve ocasión de seguir sus intervenciones en la Cámara, a propósito del debate sobre la conmemoración del Quinto Centenario, que aprovechó para apuntar magistralmente algunos aspectos sobre la identidad nacional venezolana, siempre dentro de la común identidad iberoamericana.

Mucho se podría decir de Orlando, sobre su obra, su defensa de los derechos humanos, su hispanoamericanismo, etc., pero para ello hay mejores plumas que la mía, valga simplemente mi cariñoso recuerdo al maestro y amigo que me hizo conocer y comprender su Venezuela y su América, con unos ojos diferentes a cuanto había aprendido anteriormente.

Descanse en paz, y que su ejemplo nos ayude. 